\title{
FITOKIMIA DAUN KEMANGI (Ocimum $x$ citriodorum L.) DAN PENGARUHNYA SEBAGAI WATER ADDITIVE TERHADAP KECERNAAN NUTRIEN PAKAN AYAM BROILER
}

\section{Phytochemistry of Lemon Basil (Ocimum x citriodorum L.) Leaves and Its Effect as A Water Additive on Nutrient Digestibility of Broiler Chicken Diet}

\author{
Jet Saartje Mandey ${ }^{1}$ dan Cherly Joula Pontoh ${ }^{1}$ \\ 1 Peternakan Universitas Sam Ratulangi, Sulawesi Utara \\ Email: jetsm_fapet @yahoo.co.id
}

\begin{abstract}
INTISARI
Penelitian dilakukan untuk menganalisis fitokimia daun kemangi (Ocimum x citriodorum L.) dan mengevaluasi pengaruh pemberian jus daun kemangi (JDK) sebagai aditif terhadap kecernaan nutrien pakan ayam broiler. Penelitian ini menggunakan ayam broiler jantan umur 35 hari sebanyak 20 ekor. Parameter penelitian yang diuji yaitu analisis fitokimia, proksimat, dan kecernaan pakan. Data hasil uji fitokimia dan proksimat daun kemangi dianalisis menggunakan analisis deskriptif. Data hasil uji kecernaan dianalisis menggunakan Rancangan Acak Lengkap (RAL) dengan 4 perlakuan dan 5 ulangan. Penelitian dilakukan selama 10 hari terdiri dari 7 hari periode pemeliharaan dan 3 hari periode total koleksi. Perlakuan kecernaan terdiri dari $0 \mathrm{~mL}$ JDK, $10 \mathrm{~mL}$ JDK, $20 \mathrm{~mL}$ JDK, dan $30 \mathrm{~mL}$ JDK/L air minum. Hasil penelitian menunjukkan bahwa pemberian jus daun kemangi berpengaruh baik terhadap kecernaan nutrien ayam broiler dan jus daun kemangi dapat digunakan sampai $20 \mathrm{~mL} / \mathrm{L}$ dalam air minum.
\end{abstract}

Kata kunci: Aditif, Broiler, Daun Kemangi, Fitokimia, Kecernaan Nutrien

\begin{abstract}
The study was conducted to analyze the phytochemicals of basil leaves (Ocimum x citriodorum L.) and to evaluate the effect of basil leaves juice as an additive on nutrient digestibility of broiler chicken diet. This study used 20 male broilers (35 days old). The research parameters were phytochemical, proximate, and digestibility analysis. The data of basil leaves phytochemical and proximate analysis were analyzed using descriptive analysis. The digestibility were analyzed using a Completely Randomized Design (CRD) by 4 treatments and 5 replications. The research was conducted for 10 days consisting of 7 days for maintenance period and 3 days for total collection period. The digestibility treatments consisted of $0 \mathrm{~mL}, 10 \mathrm{~mL}, 20 \mathrm{~mL}$, and $30 \mathrm{~mL}$ basil leaves juice/L drinking water. The results showed that giving basil leaves juice had a good effect on nutrient digestibility of broiler chickens and could be used up to $20 \mathrm{~mL} / \mathrm{L}$ in drinking water.
\end{abstract}

Keywords: Additive, Broiler, Lemon basil, Phytochemical, Nutrient Digestibility

\section{PENDAHULUAN}

Perubahan peraturan perundangundangan Nomor 41 Tahun 2009 untuk mengontrol penggunaan zat aditif pada ternak telah mendorong minat peternak pada penggunaan senyawa bioaktif sebagai aditif alternatif. Minat ini terutama pada peran senyawa bioaktif dalam proses pencernaan dan penyerapan. Bioaktif non-nutrien pada tumbuhan pada dasarnya adalah metabolit sekunder. Metabolit sekunder pada tumbuhan berbeda dari metabolit primer seperti karbohidrat, protein, lemak, dan asam nukleat.

Meningkatnya kesadaran dan kepedulian terhadap residu antibiotik pada produk ternak unggas di kalangan konsumen merupakan waktu yang tepat untuk mencari alternatif antibiotik pemacu pertumbuhan. 
Dalam beberapa tahun terakhir produk alami yang dikenal sebagai fitogenik telah menjadi fokus penelitian. Pakan aditif fitogenik yang berasal dari tumbuh-tumbuhan, rempahrempah atau tanaman aromatik merupakan kelas aditif yang masih baru dan telah mendapatkan perhatian yang cukup besar dalam beberapa tahun terakhir dalam industri pakan (Alagawany et al., 2016; El-Hack et al., 2016). Produk turunan tanaman ini bebas residu tidak seperti antibiotik sintetis dan juga aman untuk digunakan sebagai bahan dalam industri makanan serta dalam pakan ternak sebagai pemacu pertumbuhan yang ideal (Li et al., 2016). Minyak esensial dan ekstrak tumbuhan termasuk dalam kelompok fitokimia yang dapat digunakan sebagai alternatif aditif pakan (Alagawany et al., 2016).

Beberapa peneliti melaporkan bahwa tanaman herbal memiliki potensi aktivitas antioksidan yang dapat meningkatkan sistem kekebalan tubuh dan meningkatkan produktivitas unggas (El-Hack et al., 2016). Sebagian besar tanaman herbal memiliki aktivitas antioksidan untuk meningkatkan stabilitas oksidatif unggas, menstimulasi imunitas, meningkatkan ketahanan ayam terhadap penyakit, dan memodifikasi metabolisme lemak agar menghasilkan produk yang lebih sehat untuk dikonsumsi manusia (Upadhaya dan Kim, 2017). Ekstrak herbal memiliki manfaat bagi ternak untuk meningkatkan sekresi pencernaan, daya cerna, dan penyerapan nitrogen, serta dapat memodifikasi mikrobia usus, merangsang sistem kekebalan tubuh, meningkatkan aktivitas anti-bakteri, dan sifat anti-oksidan (Allen et al., 2013). Kecernaan nutrien yang meningkat dapat memperbaiki status kesehatan hewan.

Kemangi (Ocimum $x$ citriodorum L.) merupakan salah satu tanaman herbal yang populer di Indonesia. Di dunia dikenal dengan nama lemon basil, lemon hoary, thai lemon basil atau lao basil. Kemangi dibudidayakan untuk menghasilkan minyak atsiri yang memiliki banyak kegunaan terapeutik seperti penggunaan sebagai obat, jamu, kuliner, parfum untuk perlengkapan mandi, perawatan aromaterapi, dan sebagai agen penyedap. Kemangi (Ocimum x citriodorum L.) adalah hibrida antara basil (Ocimum basilicum) dan basil Amerika (Ocimum americanum). Daunnya berwarna hijau dan berbau khas. Kemangi mengandung minyak esensial dengan aroma sitral (Vieira dan Simon, 2006). Sitral adalah cairan berminyak berwarna kuning pucat dengan bau yang menyegarkan seperti buah lemon. Kandungan sitral dalam minyak kemangi Indonesia berkisar antara 65 sampai $70 \%$, dengan rendemen penyulingan berkisar antara 0,2 sampai 1\% (Rubiyanto, 2008).

Komponen utama minyak atsiri dari tanaman kemangi (Ocimum x citriodorum L.) adalah estragole (methylchavicol) (98,22 $\mu \mathrm{g} / \mathrm{mL})$, citral $(9,55 \mu \mathrm{g} / \mathrm{mL})$, dan neral $(6,32$ $\mu \mathrm{g} / \mathrm{mL}$ ) (Tangpao et al., 2018). Tiga senyawa utama umumnya diidentifikasi dari minyak atsiri Ocimum spp. adalah estragole (methylchavicol), eugenol, dan metil eugenol. Estragole ditemukan di O. basilicum (Verma et al., 2011; Nurzyñska-Wierdak, 2014) dan Ocimum citriodorum (Avetisyan et al., 2017). Penggunaan daun kemangi dalam makanan bermanfaat bagi kesehatan karena memiliki aktivitas antijamur, antiinflamasi, antimikroba, dan antioksidan (Alagawany et al., 2016) yang dikaitkan dengan adanya senyawa bioaktif yang berbeda termasuk fenol dan flavonoid (Li et al., 2016). Menurut Allen et al. (2013) konstituen utamanya adalah linalool, methyl chavicol, eugenol, 1,8cineole, geranial, neral, methyl cinnamate.

Aditif pakan adalah zat yang sengaja ditambahkan ke dalam pakan atau air minum untuk mempengaruhi karakteristik pakan, palatabilitas, antioksidan yang dapat meningkatkan produktivitas dan kesejahteraan hewan. Selain itu, juga mampu mempengaruhi mikrobia pada saluran pencernaaan dan meningkatkan daya cerna bahan pakan. Penelitian ini dilakukan untuk 
menganalisis fitokimia daun kemangi (Ocimum $x$ citriodorum L.) dan mengevaluasi pengaruh pemberian jus daun kemangi (JDK) sebagai aditif pakan terhadap tingkat kecernaan nutrien pakan ayam broiler.

\section{MATERI DAN METODE}

Penelitian ini menggunakan Rancangan Acak Lengkap (RAL) dengan 4 perlakuan dan 5 ulangan. Penelitian dilakukan selama 10 hari terdiri dari 7 hari periode pemeliharaan dan 3 hari periode total koleksi. Perlakuan kecernaan terdiri dari $0 \mathrm{~mL}$ JDK, $10 \mathrm{~mL}$ JDK, $20 \mathrm{~mL}$ JDK, dan $30 \mathrm{~mL}$ JDK/L air minum. Pakan dasar terdiri dari jagung kuning $60 \%$, bungkil kedelai 10\%, bungkil kelapa $7 \%$, tepung ikan $13 \%$ dan dedak padi $10 \%$. Komposisi kimia pakan adalah protein kasar 19,45\%, serat kasar 5,47\%, lemak 9,83\%, Ca 0,26\%, P 0,69\% dan energi bruto 4088 $\mathrm{Kkal} / \mathrm{kg}$. Parameter penelitian yang diuji yaitu analisis fitokimia, proksimat, dan uji keceranaan daun kemangi pada ayam broiler.

\section{Analisis Fitokimia}

Skrining fitokimia daun kemangi meliputi: 1) uji alkaloid menggunakan metode Mayer, Wagner dan Dragendorff, 2) uji saponin dilakukan dengan metode Forth, 3)uji flavonoid dilakukan dengan metode Bate Smith-Metchalf, dan 4) uji antrakuinon dilakukan dengan metode Brontrager. Kandungan total fenol diestimasi sebagai ekivalen gallic acid (Singleton et al., 1999). Kandungan flavonoid total diestimasi seperti yang dilakukan Sulaiman dan Balachandran (2012).

Pengujian aktivitas antioksidan dari daun kemangi dilakukan melalui beberapa tahapan penelitian yang meliputi: penyiapan bahan, pembuatan ekstrak, dan uji aktivitas antioksidan. Pengujian ini menggunakan metode DPPH (1,1-difenil-2-pikrilhidrazil) sebagai sumber radikal bebas. Prinsipnya adalah reaksi penangkapan hidrogen oleh
DPPH dari zat antioksidan (Tristantini et al. 2016). Rumusnya adalah sebagai berikut:

$$
\operatorname{DPPH}(\%)=\frac{\mathrm{a}-\mathrm{b}}{\mathrm{b}} \times 100
$$

Keterangan

$\mathrm{a}=$ Absorbansi kontrol

$\mathrm{b}=$ Absorbansi sampel

Analisis $\beta$-karoten dilakukan dengan Scanner Kromatografi Lapis Tipis (KLT). Kromatografi Lapis Tipis adalah metode pemisahan berdasarkan sifat fisik dimana campuran suatu senyawa didistribusikan antara fase diam dan fase gerak. Prinsipnya berdasarkan proses perpindahan atau pergeseran zat dengan kecepatan yang berbeda-beda (Sudjadi, 1985).

$R_{f}=\frac{\text { Distance traveled by the solute }}{\text { Distance traveled by the solvent front TLC plates }}$

\section{Analisis Proksimat}

Analisis proksimat terdiri dari kadar air, abu, protein kasar, lemak kasar, serat kasar, $\mathrm{Ca}$, dan $\mathrm{P}$ dilakukan menurut metode standar AOAC (2000). Energi bruto diukur dengan alat Bomb Calorimeter.

\section{Uji Keceranaan}

Uji kecernaan menggunakan ayam broiler jantan umur 35 hari sebanyak 20 ekor dalam kandang metabolis. Variabelnya adalah retensi nitrogen, energi metabolis terkoreksi nitrogen (AMEn), serat kasar, dan lemak kasar.

\section{Analisis Data}

Data hasil uji fitokimia dan proksimat daun kemangi dianalisis menggunakan analisis deskriptif. Data hasil uji kecernaan dianalisis dengan analisis varian pola searah dari Rancangan Acak Lengkap (Snedecor and Cochran, 1962) menggunakan perangkat lunak IBM SPSS Statistics 24.

\section{HASIL DAN PEMBAHASAN}

Hasil penelitian menunjukkan bahwa skrining fitokimia dengan metode visualisasi 
warna tidak berhasil menunjukkan adanya senyawa bioaktif, sedangkan dengan metode kuantitatif menggunakan spektrofotometri diperoleh total flavonoid 3,72\% (b/b), total fenol $0,19 \%(b / b)$, dan dengan titrimetri diperoleh nilai tanin $0,04 \%$ (Tabel 1). Analisis proksimat pada daun kemangi (Tabel 2.) menunjukkan nilai bahan kering 88,34\%, abu $16,13 \%$, protein kasar $27,81 \%$, lemak kasar $3,50 \%$, serat kasar $11,26 \%$, Ca $4,81 \%$, P $0,45 \%$, dan energi bruto 3807,4 Kkal (Tabel $2)$. Kadar $\beta$-karoten yang diperoleh melalui TLC Scanner adalah 2,61\%, dan kadar antioksidan IC 50\% (ppm) melalui DPPH adalah 2489,94 ppm.

Hasil penelitian tersebut menunjukkan bahwa ayam broiler yang diberi JDK dalam air minum memiliki kecernaan nutrien yang hampir sama (retensi nitrogen, AMEn, dan kecernaan lemak) dibandingkan dengan kontrol (Tabel 3). Hasil penelitian ini sejalan dengan temuan Aroche et al. (2018) yang melaporkan bahwa inklusi diet 0,50\% bubuk campuran daun tanaman obat $(60 \%$ Anacardium occidentale, $20 \% \quad$ Psidium guajava, dan $20 \%$ Morinda citrifolia) menunjukkan perubahan yang tidak signifikan terhadap parameter energi metabolis semu terkoreksi nitrogen (AMEn), kecernaan total bahan kering, dan kecernaan ileum bahan kering pada ayam pedaging.

Menurut Trasarti et al. (2004) daun kemangi memiliki potensi antioksidan tertinggi diikuti oleh bunga dan batang. Potensi antioksidan dalam minyak atsiri daun kemangi lebih tinggi dibandingkan bagian tanamannya. Aktivitas antioksidan minyak atsiri tertinggi adalah $200 \mathrm{ppm}(74,11 \%)$, disusul 100 ppm (70,27\%). Pada konsentrasi ekstrak tumbuhan 50 ppm aktivitas antioksidan sebanyak 46,81\%. Konsentrasi ekstrak daun $50 \mathrm{ppm}$ aktivitas antioksidan sebanyak 65,62\%. Lebih lanjut Bunwijit et al. (2017) melaporkan bahwa ekstrak daun Ocimum africanum dapat mencegah tukak lambung melalui efek antioksidatif dan antiinflamasi. Tanaman aromatik bermanfaat untuk perlindungan gastro intestinum. Kahkonen et al. (1999) melaporkan bahwa aktivitas antioksidan suatu tanaman berhubungan dengan total fenol yang dikandungnya.

Tabel 1. Fitokimia Daun Kemangi

\begin{tabular}{|c|c|c|c|c|}
\hline \multicolumn{2}{|c|}{ Fitokimia } & Hasil & Satuan & Teknik Analisis \\
\hline \multirow[t]{2}{*}{ Flavonoid } & & Negatif & - & \\
\hline & Wagner & Negatif & - & \\
\hline \multirow[t]{2}{*}{ Alkaloid } & Mayer & Negatif & - & \\
\hline & Dragendorf & Negatif & - & \\
\hline Tanin & & Negatif & - & Visualisasi Warna \\
\hline Saponin & & Negatif & - & \\
\hline Kuinon & & Negatif & - & \\
\hline Steroid & & Negatif & - & \\
\hline Triterpenoid & & Negatif & - & \\
\hline Total flavonoid & & 3,72 & $\%(b / b)$ & Spectrophotometer \\
\hline Total fenol & & 0,19 & $\%(b / b)$ & Spectrophotometer \\
\hline Tanin & & 0,04 & $\%$ & Titrimeter \\
\hline$\beta$-karoten & & 2,61 & $\%$ & TLC Scanner \\
\hline Antioksidan IC 50\% & & 2489,94 & ppm & DPPH/Spectrophotometer \\
\hline
\end{tabular}

Kandungan flavonoid total pada penelitian ini lebih tinggi daripada jenis Ocimum lainnya. Akinmoladun (2007) melaporkan bahwa Ocimum gratissimum mengandung flavonoid, steroid, glikosida jantung, tanin, dan flobatanin. Hakkim et al. (2008) menjelaskan bahwa hasil analisis fitokimia ekstrak spesies Ocimum 
mengandung 11 senyawa fenol (asam rosmarinat, asam litospermat, asam vanilat, asam p-kumarat, asam hidroksibenzoat, asam siringat, asam kafeat, asam ferulat, asam sinamat, asam hidroksil fenil-laktat, dan asam sinapat). Ekstrak tumbuhan tersebut menunjukkan aktivitas antioksidan yang baik.

Aktivitas antioksidan pada penelitian ini (nilai IC 50\% sebesar 2.489,94 ppm) lebih tinggi daripada dengan yang dilaporkan Erviana et al. (2011) bahwa ekstrak etanol daun kemangi (Ocimum basilicum L.) memiliki aktivitas antioksidan sedang (nilai IC 50\% sebesar 52,68 $\mu \mathrm{g} / \mathrm{mL}$ ). Pada uji pembilasan radikal bebas ekstrak etanol memiliki aktivitas sedang (nilai IC 50\% sebesar 52,68 $\mu \mathrm{g} / \mathrm{mL}$ ) lebih rendah dari kuersetin (nilai IC $50 \%$ sebesar $1,8 \mu \mathrm{g} / \mathrm{mL}$ ). Tahira et al. (2013) melaporkan bahwa nilai rata-rata aktivitas antioksidan yang dimiliki oleh berbagai konsentrasi ekstrak tumbuhan dan minyak esensial lemon basil. Hasilnya menunjukkan bahwa aktivitas antioksidan tertinggi $(74,11 \%)$ tercatat pada konsentrasi minyak atsiri $200 \mathrm{ppm}$ diikuti oleh minyak atsiri 100 ppm (70,27\%). Konsentrasi minyak atsiri bekerja lebih baik daripada konsentrasi ekstrak tumbuhan. Minyak atsiri memiliki aktivitas antioksidan lebih tinggi daripada ekstrak tumbuhan dan daun kemangi memiliki potensi antioksidan tertinggi $(65,62 \%)$ diikuti oleh bunga dan batang.

Tabel 2. Komposisi Kimia Daun Kemangi

\begin{tabular}{|c|c|}
\hline Komposisi & Hasil \\
\hline Bahan kering (\%) & 88,34 \\
\hline Abu (\%) & 16,13 \\
\hline Protein kasar (\%) & 27,81 \\
\hline Lemak kasar (\%) & 3,5 \\
\hline Serat kasar (\%) & 11,26 \\
\hline Сa (\%) & 4,81 \\
\hline $\mathrm{P}(\%)$ & 0,45 \\
\hline Energi bruto (Kkal) & $3,808,40$ \\
\hline
\end{tabular}

Menurut Patel et al. (2010) alkaloid, steroid, flavonoid, dan polifenol merupakan senyawa aktif yang telah terbukti antioksidan, antiinflamasi, dan imunomodulator. Aditif seperti tumbuhan aromatik atau minyak atsiri dapat membantu hewan untuk tumbuh lebih baik, bebas dari tekanan selama situasi kritis, dan meningkatkan ketersediaan nutrien penting di usus. Ekstrak tumbuhan dapat merangsang sistem kekebalan tubuh, menekan mikroorganisme berbahaya seperti E. coli, Eimeria spp., C. perfringens, Mycoplasma gallisepticum), dan stimulasi mikroba bermanfaat seperti Lactobacillus spp. (Tahira et al., 2013). Ocimum x citriodorum L. dilaporkan aktif sebagai antimikroba terhadap Staphylococcus aureus, Staphylococcus epidermis, Streptococcus mutans, Lactobacillus casei, Listeria ivanovii, L. monocytogenes, Enterococcus faecalis, E. faecium, Escherichia coli, dan Proteus mirabilis (Carovic-Stanko et al., 2010).

Tingkat retensi yang lebih tinggi mencerminkan kecernaan protein yang lebih baik. Retensi nitrogen menunjukkan zat $\mathrm{N}$ yang tertahan di dalam tubuh (pakan $\mathrm{N}$ diserap oleh tubuh) dan yang tidak diserap akan diekskresikan dalam ekskreta. Menurut Sibbald (1978) faktor yang mempengaruhi kecernaan protein pada unggas adalah umur unggas, laju pertumbuhan, reproduksi (jenis kelamin), iklim, tingkat energi, penyakit, spesies, dan strain. Energi yang terkandung dalam bahan pakan unggas (energi bruto), tidak seluruhnya dimanfaatkan dalam tubuh unggas sebagai sumber energi, sebagian terbuang melalui ekskreta. Jumlah energi yang dapat dimanfaatkan dalam tubuh unggas disebut energi metabolis (Leeson and Summer, 2005). 
Tabel 3. Pengaruh Daun Kemangi Dalam Air Minum Terhadap Kecernaan Nutrien Ransum Ayam Pedaging

\begin{tabular}{lcccccc}
\hline \multirow{2}{*}{\multicolumn{1}{c}{ Paremeter }} & \multicolumn{3}{c}{ Perlakuan } & \multicolumn{2}{c}{ SEM } & $\begin{array}{c}p \\
\text { Value }\end{array}$ \\
\cline { 2 - 7 } & $0 \mathrm{ml} \mathrm{JDK}$ & $10 \mathrm{ml} \mathrm{JDK}$ & $20 \mathrm{ml} \mathrm{JDK}$ & $30 \mathrm{ml} \mathrm{JDK}$ \\
\hline Retensi nitrogen (\%) & 99,30 & 98,83 & 99,16 & 98,59 & 0,15 & 0,34 \\
AMEn (Kkal/kg) & 2.770 & 2.754 & 2.762 & 2.707 & 48,6 & 0,65 \\
Kecernaan lemak (\%) & 95,12 & 94,42 & 94,39 & 93,20 & 0,48 & 0,27 \\
Kecernaan serat kasar (\%) & $70,44^{\mathrm{a}}$ & $70,00^{\mathrm{a}}$ & $71,67 \mathrm{a}$ & $65,00^{\mathrm{b}}$ & 0,93 & 0,04 \\
\hline
\end{tabular}

${ }^{\mathrm{ab}}$ superskrip yang berbeda pada baris yang sama menunjukkan perbedaan yang berbeda nyata $(\mathrm{P}<0,05)$

Menurut Lee (2001) peran antibiotik adalah mengatur keseimbangan optimal mikrobia usus unggas (antara Gram negatif dan Gram positif). Mikrobia usus yang seimbang adalah $90 \%$ bakteri Gram positif (terutama Lactobacillus), dan selama stres jumlah mikrobia patogen seperti Escherichia coli atau Gram negatif lainnya meningkat. Bakteri Gram negatif dapat menyebabkan peradangan pada mukosa usus sehingga mengurangi penyerapan nutrien. JDK diduga bekerja secara positif pada usus dan metabolisme nutrien ayam broiler.

Hernandez (2004) melaporkan bahwa semua aditif (ekstrak minyak esensial dari oregano, kayu manis, dan lada) dan ekstrak Labiatae (sage, thyme, dan rosemary) meningkatkan kecernaan bahan kering dan protein kasar pakan. Mahmood et al. (2015) melaporkan bahwa suplementasi ekstrak daun Azadirachta indica 4\% menunjukkan kecernaan protein kasar dan lemak kasar yang lebih baik daripada kontrol. Namun, serat kasar tidak memiliki kecernaan yang berarti akibat perlakuan tersebut.

Aditif pakan fitogenik telah dilaporkan dapat meningkatkan kinerja, rasio konversi pakan, keamanan, dan kualitas daging karkas pada hewan (Stanacev et al., 2011; Dhama et al., 2014, 2015). Selain meningkatkan kinerja, fitogenik juga memiliki sifat antioksidan yang efeknya terkait dengan minyak esensial (EO) dan komponennya (Alagawamy et al., 2016). Fitogenik juga memiliki efek menguntungkan pada pemanfaatan nutrien dengan menstimulasi enzim pencernaan seperti lipase, amilase, atau protease, dan dapat memperbaiki morfologi gastrointestinal (Upadhaya et al., 2016).

Mikroflora usus merupakan faktor penting untuk kesehatan dan hasil produksi unggas. Mikroflora tersebut penting untuk keselamatan konsumen, karena mikrobia patogen pada isi usus dapat mencemari karkas, seperti Staphylococcus aureus, Escherichia coli, Listeria monocytogenes, Clostridium perfringens, Campylobacter, dan Salmonella (Choi et al., 2015). Komposisi mikroflora usus secara kualitatif dan kuantitatif pada unggas dipengaruhi oleh banyak faktor, misalnya stres lingkungan, kondisi kandang, iklim mikro, umur unggas, dan komposisi pakan. Homeostasis mikroflora gastrointestinal dapat dipengaruhi oleh suplementasi pakan dengan zat aktif tertentu, seperti minyak atsiri (Roberts et al., 2015). Oleh karena itu, minyak esensial dalam pakan dapat meningkatkan pertumbuhan unggas. Mikroflora usus dapat menghidrolisis garam empedu terkonjugasi yang membatasi pencernaan lemak (Lee et al., 2004).

Semakin panjang vili dan luas permukaan usus pada unggas maka semakin meningkatkan penyerapakan nutrien pakan (Zeng et al., 2015; Franz et al., 2010). Minyak atsiri dapat mempengaruhi fungsi usus dengan merangsang sekresi pencernaan dan dapat meningkatkan aktivitas enzim (Manzanilla, et al., 2004). Amad et al. (2011) melaporkan bahwa kecernaan ileum abu, protein kasar, lemak kasar, kalsium, dan fosfor menunjukkan peningkatan linier terkait dengan peningkatan aditif pakan fitogenik dalam pakan. 


\section{KESIMPULAN}

Hasil penelitian menunjukkan bahwa pemberian jus daun kemangi berpengaruh baik terhadap kecernaan nutrien ayam broiler dan jus daun kemangi dapat digunakan sampai $20 \mathrm{~mL} / \mathrm{L}$ dalam air minum.

\section{UCAPAN TERIMA KASIH}

Penulis menyampaikan terimakasih kepada LPPM-Unsrat yang telah memberikan dukungan dana penelitian RDUU.

\section{DAFTAR PUSTAKA}

Akinmoladun, C., E.O. Ibukun, E. Afor, E.M. Obuotor, and E.O. Farombi. 2007. Phytochemical constituent and antioxidant activity of extract from the leaves of Ocimum gratissimum. Scientific Research and Essay. 2(5):163-166.

Alagawany, M., E.A. Ashour, and F.M. Reda. 2016. Effect of dietary supplementation of garlic (Allium ativum) and turmeric (Curcuma longa) on growth performance, carcass traits, blood profile and oxidative status in growing rabbit. Annual Animal Science. 16:489505.

Allen, H.K., U.Y. Levine, T. Looft, M. Bandrick, and T.A. Casey. 2013. Treatment, promotion, commotion: antibiotic alternatives in food-producing animals. Trends in Microbiology. 21(3): 114-119.

Amad, A.A., K. Manner, K.R. Wendler, K. Neumann, and J. Zentek. 2011. Effects of a phytogenic feed additive on growth performance and ileal nutrient digestibility in broiler chickens. Poultry Science. 90:2811-2816.

AOAC. 2000. Official methods of analysis. Association of Official Analytical Chemist. Washington, D.C.

Aroche, R., Y. Martı'nez, Z. Ruan, G. Guan, S. Waititu, Ch. M. Nyachoti, D. Ma's, and S. Lan. 2018. Dietary inclusion of a mixed powder of medicinal plant leaves enhances the feed efficiency and immune function in broiler chickens. Journal of Chemistry. 2018: 1-6.
Erviana R., S. Purwono, and Mustofa. 2011. Activecompounds isolated from red betel (Piper crocatumRuiz \& Pav) leaves active against Streptococcus mutans through its inhibition effect on glucosyltransferaseactivity. Journal of the Medical Scieneces. 43(2):71-78.

Avetisyan, A., A. Markosian, M. Petrosyan, N. Sahakyan, A. Babayan, S. Aloyan, and A. Trchounian. 2017. Chemical composition and some biological activities of the essential oils from basil Ocimum different cultivars. BMC Complement Alternate Medicine. 17(1):1-8.

Bunwijit, J., B. Sripanidkulchai, W. Pannangrong, J. Junlatat, and K. Sripanidkulchai. 2017. Gastroprotective effect of hydroalcoholic extract of Ocimum africanum leaves. Songklanakarin Journal Science Technology. 39(4):539-547.

Carovic-Stanko, K., S. Orlic, O. Politeo, F. Strikic, I. Kolak, M. Milos, and Z. Satovic. 2010. Composition and antibacterial activities of essential oils of seven Ocimum taxa. Food Chemistry. 119(1): 196-201.

Choi, K.Y., T.K. Lee, and W.J. Sul. 2015. Metagenomic analysis of chicken gut microbiota for improving metabolism and health of chickens - a review. Asian-Australasian Journal of Animal Science. 28(9): 1217-1225.

Dhama, K., S. Chakraborty, R. Tiwari, A.K. Verma, M. Saminathan, Y.S. Amarpal Malik, Z. Nikousefat, M. Javdani, and R.U. Khan. 2014. A concept paper on novel technologies boosting production and safeguarding health of humans and animals. Research Opinion Animal Veteriner Science. 4(7): 353-370.

Dhama, K., S.K. Latheef, S. Mani, H.A. Samad, K. Kartik, R. Tiwari, R.U. Khan, M. Alagawany, M.R. Farag, G.M. Alam, V. Laudadio, and V. Tufarelli. 2015. Multiple beneficial applications and modes of action of herbs in poultry health and production - a review. Inernational Journal Pharmacology. 11: 152-176.

El-Hack, M.E.A., M. Alagawany, M.R. Farag, R. Tiwari, K. Karthik, K. Dhama, J. Zorriehzahra, and M. Adel. 2016. 
Beneficial impacts of thymol essential oil on health and production of animals, fish and poultry. A review. Journal Essential Oil Research. 28(5):365-382.

Franz, C., K.H.C. Baser, and W. Windisch. 2010. Essential oils and aromatic plants in animal feeding. a European perspective - a review. Flavour Fragnance Journal. 25(5):327-340.

Hakkim, G., Arivazhagan, and R. Boopathy. 2008. Antioxidant property of selected Ocimum species and their secondary metabolite content. Journal of Medicinal Plants Research. 2(9): 250-257.

Kahkonen, M.P., A.I. Hopia, H.J. Vuorela, J. Rauha, K. Pihlaja, S.T. Kujala, and M. Heinonen. 1999. Antioxidant activity of plant extracts containing phenolic compounds. Journal Agriulture Food Chemistry. 47(10):3954-3962.

Lee, K. G. and T. Shibamoto. (2001). Inhibition of malonaldehyde formation from blood plasma oxidation by aroma extracts and aroma components isolated from clove and eucalyptus. Food and Chemical Toxicology. 39: 1199-1204.

Lee, K.W., H. Everts, and A.C. Beynen. 2004. Essential oils in broiler nutrition. International Journal of Poultry Science. $3(2): 738-752$.

Leeson, S. and J.D. Summers. 2005. Commercial Poultry Nutrition. $3^{\text {rd }}$ Ed. Nottingham University Press. Nottingham.

Li, H. N., P.Y. Zhao, L. Yan, M.M. Hossain, J. Kang, and I.H. Kim. 2016. Dietary phytoncide supplementation improved growth performance and meat quality of finishing pigs. Asian Australaian Journal Animal Science. 29(9): 1314-1321.

Mahmood, S., A. Rehman, M. Yousaf, P. Akhtar, G. Abbas, K. Hayat, A. Aisha Mahmood, and M.K. Shahzad. 2015. Comparative efficacy of different herbal plant's leaf extract on haematology, intestinal histomorphology and nutrient digestibility in broilers. Advance in Zoology and Botany. 3(2): 1-16.

Manzanilla, E.G., J.F. Perez, M. Martin, C. Kamel, F. Baucells, and J. Gasa. (2004). Effect of plant extracts and formic acid on the intestinal equilibrium of earlyweaned pigs. Journal of Animal Science. 82(11):3210-3218.
Patel, M.A., P.K. Patel, and M.B. Patel. 2010. Aqueous extract of Ficus bengalensis Linn. Bark for inflammatory bowel disease. Journal of Young Pharmacology. 2(2):130-136.

Roberts, T., J.Wilson, A. Guthrie, J.Cookson, D. Vancraynest, K. Schaeffer, R. Moody, and S. Clark. 2015. New issues and science in broiler chicken intestinal health: Emerging technology and alternative interventions. Journal Applied Poultry Research. 24(7):256-266.

Rubiyanto, D. 2008 . The Essential Oil of "Daun Kemangi" (Ocimum Citriodorum Sp.) and Preliminary Study of Its Impacton the Grasshopper Feeding. Malaysian International Conference on Essential Oil. Flavor and Fragrance Materials V(MICEOFF5). 28-30 Oktober 2008. Institut Kimia Malaysia. Kuala Lumpur.

Sibbald, R. 1978. A bioassay for true metabolizable energy in feeding stuff. Poultry Science Journal. 55(1):896-899.

Singleton, V.L., R. Orthofer, and R.M. LamuelaRavento. 1999. Analysis of total phenols and other oxidation substrates and antioxidants by means of Folin-Ciocalteu reagent. In: L. Packer. Eds. Methods in Enzymology. San Diego CA. Academic Press. San Diego. pp. 152-178.

Snedecor, G.W. and W.G. Cochran. 1962. Statistical Methods. Applied to Experiments in Agriculture and Biology. $5^{\text {th }}$ Ed. Iowa State University Press. Ames.

Stanacev, V., D. Glamocic, N. Milosevic, N. Puvaca, V. Stanacev, and N. Plavsa. 2011. Effect of garlic (Allium sativum L.) in fattening chicks nutrition. African Journal Agriulture Research. 6(4):943948.

Sudjadi. 1985. Penentuan Struktur Senyawa Organik. Ghalia Indonesia. Jakarta.

Sulaiman, C. T. and I. Balachandran. 2012. Total Phenolics and flavonoids in selected Indian medicinal plants. Indian Journal of Pharmaceutical Science. 74(3):258-260.

Tahira, R., T. Rehan, A. Rehman, and M. Naeemullah. 2013. Variation in bioactive compounds in different plant parts of lemon basil (Ocimum Basilicum 
Var. citriodorum). The Experiment. 17(2):1184-1190.

Tangpao, T., Hsiao-Hang Chung, and S. R. Sommano. 2018. Aromatic profiles of essential oils from five commonly used Thai basils. Foods. 7(11):175-188.

Trasarti, F., A.J. Marchi, and C.R. Apesteguia. 2004. Highly selective syntheses of menthols from citral in a one - step one process. Journal of Catalysis. 224(2): 484-488.

Tristantini, D., A. Ismawati, B.T. Pradana, and J.G. Jonathan. 2016. Pengujian aktivitas antioksidan menggunana metode DPPH pada daun tanjung (Mimusops elengi L.). Prosiding Seminar Nasional Teknik Kimia "Kejuangan". 12 Maret 2016. Yogyakarta. pp. G1-1-G1-7.

Upadhaya, S.D., S.J. Kim, and I.H. Kim. 2016. Effects of gel-based phytogenic feed supplement on growth performance, nutrient digestibility, blood characteristics and intestinal morphology in weanling pigs. Journal Applied Animal Research. 44(1):384389.

Upadhaya, S.D. and I.H. Kim. 2017. Efficacy of phytogenic feed additive on performance, production and health status of monogastric animals. A Review. Annual Animal Science. 17(4):929-948.

Verma, R.S., P.S. Bisht, R.C. Padalia, D. Saikia, and A. Chauhan. 2011. Chemical composition and antibacterial activity of essential oil from two Ocimum spp. grown in sub-tropical India during spring-summer cropping season. Asian Journal Traditional Medicinal. 6(5):211217.

Vieria, R.F. and J.E. Simon. 2006. Chemical characterization of basil (Ocimum spp.) based on volatile oils. Flavour and Fragrance Journal. 21(2): 214-221.

Zeng, Z., S. Zhang, H. Wang, and X.X. Piao. 2015. Essential oil and aromatic plants as feed additives in non-ruminant nutrition - a review. Journal Animal Science Biotechnology. 6(1):7. 